This item was submitted to Loughborough's Research Repository by the author.

Items in Figshare are protected by copyright, with all rights reserved, unless otherwise indicated.

\title{
Constructing crime, enacting morality: emotion, crime and anti-social behaviour in an inner-city community
}

PLEASE CITE THE PUBLISHED VERSION

http://dx.doi.org/10.1093/bjc/azq029

PUBLISHER

Oxford University Press on behalf of the Centre for Crime and Justice Studies (ISTD) / @ The Author 2010

VERSION

AM (Accepted Manuscript)

LICENCE

CC BY-NC-ND 4.0

\section{REPOSITORY RECORD}

Cromby, John, Steven D. Brown, Harriet Gross, Abigail Locke, and Anne Patterson. 2019. "Constructing Crime, Enacting Morality: Emotion, Crime and Anti-social Behaviour in an Inner-city Community”. figshare. https://hdl.handle.net/2134/11068. 
This item was submitted to Loughborough's Institutional Repository (https://dspace.lboro.ac.uk/) by the author and is made available under the following Creative Commons Licence conditions.

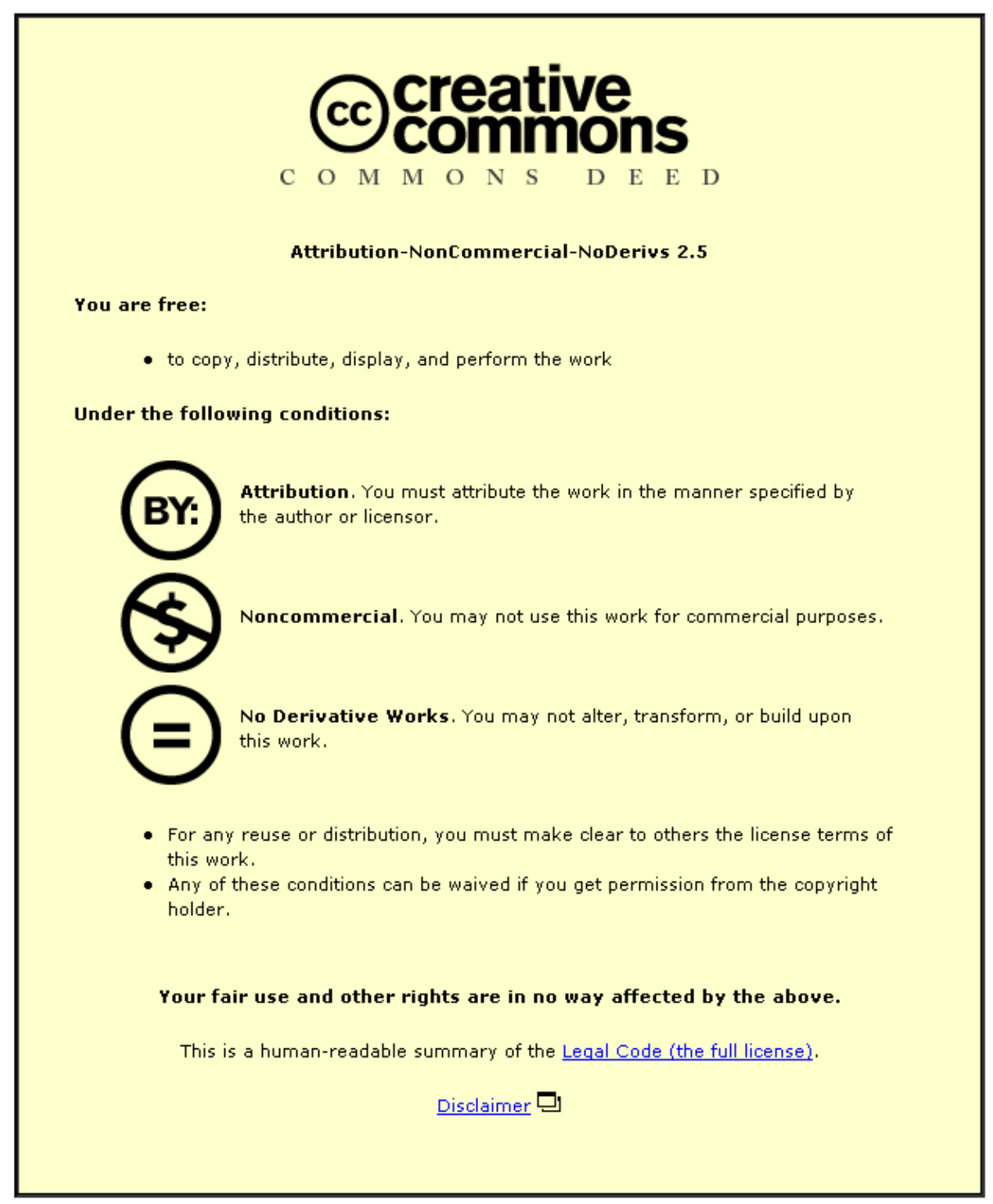

For the full text of this licence, please go to: http://creativecommons.org/licenses/by-nc-nd/2.5/ 
Constructing crime, enacting morality: emotion, crime and anti-social behaviour in an inner-city community

John Cromby

Steven D.Brown

Harriet Gross

Abigail Locke

Anne. E. Patterson

Published: British Journal of Criminology 50 (5) 873-895, 2010

Numbers in square brackets [p.xx] refer to page numbers in the printed version

Contact:

John Cromby

Psychology Division, SSEHS

Loughborough University

Loughborough, Leics. UK LE11 3TU

Tel: 01509223000

J.Cromby@lboro.ac.uk 
[p.873]

Constructing crime, enacting morality: emotion, crime and anti-social behaviour in an inner-city community

\begin{abstract}
Research into emotion, crime and anti-social behaviour has lacked psychological input and rarely considered the multi-directional associations between emotion, crime and morality. We present a study analysing audio recordings of two community groups meeting in a deprived inner city area with high rates of crime, using conversation analytic and discursive psychological techniques to conduct an affectivetextual analysis that draws out aspects of participants' moral reasoning and identifies its emotional dimensions. Moral reasoning around crime and ASB took three forms (invoking moral categories, developing moral hierarchies, invoking vulnerable others), and was bound up with a wide range of emotional enactments and emotion displays. Findings are discussed in relation to contemporary government policy and possible future research.
\end{abstract}

\title{
Introduction
}

Across the social sciences and humanities, there has recently been what is being called an affective turn: a resurgent interest in emotion, feeling and affect, understood as hybrid, embodied phenomena neither simply biological nor wholly reducible to social influence (Athanasiou, Hantzaroula, \& Yannakopoulos, 2008; Blackman \& Cromby, 2007; Clough \& Halley, 2007). Within criminology, De Haan \& Loader (2002) described the discipline as facing a new 'aetiological crisis' that might best be resolved by taking account of the affective dimensions of criminal behaviour, in order to better comprehend the motives of offenders. They argue that there are both historical and intuitive, normative links between emotion, crime and social control; that current Anglo-American discourse on crime bears an increasingly heightened emotional tone, and that emotion is 'inescapably implicated' in late modern penality. Karstedt (2002) makes the related argument that in recent years there has been a widespread 'emotionalisation' of law and justice. On the one hand contemporary emphases on individuality and autonomy have led to greater value being placed on 'authentic' emotion displays; on the other, global media increasingly promulgate emotionalised practices of compassion, sympathy, sorrow and rage that position 
audiences as moral spectators of distant suffering. Karstedt argues that penal law and criminal justice systems have responded to these societal changes with a 'rediscovered' moral imagination that especially emphasises shame and orients toward public and collective emotion displays. In the same vein, Yar (2009) questions criminology's partitioning of reason and emotion, arguing that it has produced an over-reliance on notions of rational actors that has blinded analysts to the reasonability [p.874] of emotion. Nevertheless, recent criminological engagement with emotion has been largely restricted to studies of the sensuous thrills and illicit passions of offending (Ferrell, 2003; Katz, 1998, 1999), analyses of the emotional dimensions of criminal justice and restitution (Karstedt, 2002; Scheff \& Retzinger, 1991; van Stokkom, 2002), and research within the 'fear of crime' paradigm.

Another way in which criminological research on emotion may appear relatively restricted is with respect to its disciplinary origins. The vast majority has been conducted by criminologists, geographers and sociologists, and despite the seemingly obvious relevance of their disciplinary expertise there has been relatively little input from psychologists. Katz's work is informed by social psychology and there has been a strand of psychologically-informed work using a psychoanalytic frame to explore the ways in which fear and anxiety about crime appear as defensive and defended responses within the context of individual biographies (Gadd \& Jefferson, 2007; Hollway \& Jefferson, 1997); within criminology there have also been calls to deploy psychological definitions of emotion and notions of appraisal and cognition (Jackson, 2006). But other relevant psychological perspectives have had little impact: for example, work on the neuroscience and experimental psychology of emotion, social and cultural psychological studies of emotion discourse, and discursive psychological and conversation analytic approaches, have not significantly informed criminology.

One possible consequence of this relatively narrow focus is that it seems to have largely precluded empirical consideration of the everyday associations between crime and anti-social behaviour (hereafter, ASB), emotion and morality. Such work seems timely within an emotionalised legal and juridical climate, and might illuminate the moral character of recent and current government initiatives. ASB became a prominent object of public concern and government policy during the 1990's, especially under the 1997 New Labour administration; however, its roots lay in earlier 
Conservative policy, and its continuing significance has been noted under Cameron's Conservative leadership (Millie, 2009). Despite its high profile, ASB remains a contested concept: its emphasis on the subjective possibilities for harassment and distress blurs and extends the boundaries of criminality, whilst its enforcement primarily through anti-social behaviour orders or ASBO's - disproportionately impacts those who are already marginalised and dispossessed (BIBIC, 2005; Fyson \& Yates, in press; Nixon, Hodge, Parr, Willis, \& Hunter, 2008). Crawford (2009) asserts that the ASB agenda is preoccupied with the question of governing young people, and that it challenges traditional conceptions of criminal justice through an increased emphasis on the quasi-informal regulation of individual behaviour.

Discussions of ASB frequently mobilise notions of 'respect', notably within the wellpublicised 'Respect' agenda (Home Office, 2006b). Like the ASBO, this agenda addressed various issues: begging, noise, street-drinking, drugs, prostitution and flytipping were included, but so were high hedges, graffiti, parenting and noisy smokers outside pubs (Home Office, 2009). Whilst respect has been less prominent within national policy in recent years, it continues to inform local initiatives: in Nottingham, where the empirical research reported here was conducted, a 2003 initiative "Respect for Nottingham" is now a high-profile "city-wide partnership committed to tackle low level crime and anti-social behaviour", with an action plan stretching until 2012 which explicitly promotes 'respect and consideration' (Nottingham Crime and Drugs Partnership, 2007). But respect, too, is controversial as a medium for and target of policy: as a prominent element of what Sayer (2005) calls 'lay morality', respect is normative, [p.875] and yet cannot be imposed from above (Sennett, 2003); attempts to do so may actually reinforce social exclusion by falsely rendering the standards of dominant groups as an ostensibly neutral 'civility' (Sen, 2007). By emphasising that respect 'cannot be learned, purchased or acquired, it can only be earned' (Home Office, 2006b), policy devalues those who have not managed to 'earn' the respect of others, elides the responsibility of government to foster mutual respect between individuals and institutions, and ignores how individuals and institutions with power and status may themselves be disrespectful (Harris, 2006). Respect fundamentally requires mutuality and equality, but policy initiatives on 'respect' have not addressed inequality, and ignore the basic inequality between government and its citizens (Somerville, 2009). 
Moreover, independently of this policy context there is good interdisciplinary evidence for multi-directional links between crime and ASB, morality, and emotion. First, crime and morality are interwoven, but not equivalent: although crime is defined by legal codes that often echo moral injunctions, morality does not always coincide with legality. The relations between legality and morality are often most visibly contested with respect to issues such as abortion (Stretton, 2006), euthanasia (Atari, 2008) and homosexuality (Greenberg \& Bailey, 1993), although in everyday life they frequently appear in more mundane ways. Karstedt \& Farrall (2006) discuss various 'everyday' crimes on the fringes of both legality and morality, such as jumping red traffic lights, inflating insurance claims, or misrepresenting one's home address to gain a place at a favoured school. They show how the prevalence of such practices is normatively bound up with moral economies (particular configurations of justice perceptions, regulatory regimes, profits and entitlements, and behavioural and role expectations), and provide evidence suggesting that these moral economies are influenced by wider economic and social conditions. When we broaden our focus to include ASB, the fit with morality becomes even more complex: although the 1998 Crime and Disorder Act defined ASB relatively clearly as "acting in a manner that caused or was likely to cause harassment, alarm or distress to one or more persons not of the same household as the complainant", in practice ASB is a hugely elastic concept (Scraton, 2004). Millie (2008) argues that not only are judgements about ASB informed by the behavioural expectations associated with places, events and situations, but also that other considerations, particularly the aesthetic, often come into play. Relatedly, qualitative studies of everyday incivilities provide evidence that people frequently take moral stances toward behaviours that are not necessarily illegal, but which are considered inappropriate or threatening (Phillips \& Smith, 2003).

Emotion and morality are also closely linked. Historically, moral philosophers frequently held that emotions were irrational, biasing influences upon the rational application of proper moral judgement, but in recent years this view has changed and emotions are now widely seen as making both communicative and informational contributions to moral judgements (Ben-Ze-ev, 1997). Moreover, contemporary neuroscience and psychology furnish extensive evidence of links between morality 
and emotion. The recent discovery of mirror neurons (Gallese \& Goldman, 1998) neurons that fire when expressions and actions are performed, and when the same expressions or actions are observed - has led to the suggestion that these neurons are the organic basis of empathy, an emotion usually seen as a key component of moral reasoning (Haidt, 2003). Whatever the eventual status of this strong claim, numerous brain imaging and neuro-anatomical studies also suggest that emotions and feelings of various kinds contribute [p.876] significantly to everyday moral reasoning (ImordinoYang \& Damasio, 2007). A recent review of experimental psychological evidence similarly found good evidence for the involvement of guilt, shame and empathy in moral judgement, and less extensive evidence that other emotions (happiness, sadness, anger) also contribute (Eisenberg, 2000). In recent years, the ways that children acquire the ability to make moral judgements alongside their growing ability to differentiate and regulate emotion have also been extensively studied (Barrett, Zahn-Waxler, \& Cole, 1993). Similarly, discursive psychological studies of everyday reasoning and decision-making show that emotions and emotion displays get regularly invoked as people negotiate their moral worlds (e.g. Edwards, 1999; Locke \& Edwards, 2003; Stokoe \& Edwards, 2007; Tileaga, 2007).

Finally, the fear of crime paradigm provides extensive empirical evidence that crime and ASB engender emotion. Whilst levels of reported fear in the UK have declined since the 1980's, recent surveys still reveal significant levels of concern. The majority of earlier surveys deployed some variant of the so-called 'standard question': "how safe would you feel walking alone in your neighbourhood at night?" (Hale, 1996). More recent research probing actual rather than hypothetical fear (e.g. "have you worried about $\mathrm{x}$ in the past 12 months? How many times have you worried about $\mathrm{x}$ in the last 12 months") not only finds lower levels of fear, but also that fears may act as 'barometers' for perceptions of social cohesion and moral consensus (Gray, Jackson, \& Farrall, 2008). In recent years, qualitative studies have become increasingly common, and have similarly provided evidence suggesting that surveys may overestimate actual levels of fear. Qualitative studies further suggest that emotional responses to crime are variable, transitory and situational (Pain, 1997, 2000), may arise differently for parents (Tulloch, 2004), children (Nayak, 2003) older people (Tulloch, 2000) and ethnic minorities (Chakraborti \& Garland, 2003), and follow the contours of local 'social geographies' that inform participants' understandings. 
Qualitative studies also show that other emotions than fear are prompted by crime and that different emotions arise according to whether crime is experienced directly, witnessed, or simply contemplated (Phillips \& Smith, 2003).

So it seems that there are complex, multi-directional associations between crime and ASB, emotion and morality, and that research exploring the dense nexus of their intersection might be valuable. Smith (1999) highlights the central role of communities in locating and promulgating moralities. Communal ties provide the oftunrecognised 'structures of feeling' (Taylor, Evans, \& Fraser, 1996) or background assumptions (Benson, 2001; Shotter, 1993a, 1993b) against which moral judgements are actually made; these judgements always arise within a web of debts, inheritances, expectations and obligations (MacIntyre, 1985). Consequently, moralities are already thoroughly bound up with social relations, such that everyday social interaction is an appropriate site for discursive psychological studies of their operation (Stokoe \& Wallwork, 2003). Moralities are frequently contested and contradictory, and their heterogeneity can be related to conflicting moral philosophies and the notions of 'community' they rely upon. Smith (1999) notes the different concepts of community deployed in liberalism and communitarianism. Liberalism frequently represents community as a freely-chosen adjunct to the activities of a rational individual, and so with respect to morality is arguably too individualistic, a-historical, insensitive to the material sources of selfhood, and overly concerned with rights rather than relationships. Communitarianism is said to overcome these difficulties by conceptualising selves as relational, located within 'constitutive [p.877] communities' that provide communal bonds and socio-spatial hierarchies of duties and responsibilities. Nevertheless, its claimed advantages are themselves contested on the grounds that it harkens back to an idealised past, fosters protectionism, is intolerant of diversity, downplays the significance of gendered power relations, and does not take adequate account of material differences in power and wealth.

Clearly, therefore, community cannot simply be an abstract 'warm fuzzy', automatically preferable to the anomie of wider society (Sayer \& Storpor, 1997); its associations with morality call for empirical investigation. Communities can be defined in terms of common needs and goals, a sense of the common good, shared lives, culture and views of the world, and shared or collective action (Silk, 1999). 
Some communities have a clear territorial basis and can be defined in terms of bounded geographical space, whereas others are more 'stretched out' and spatially dispersed, their social relations mediated by communication technologies and not isomorphic with any given spatial form (Allen \& Hamnett, 1995; Miller, 1993). The 'imagined communities' of nationhood (Anderson, 1991) contain elements of both in that they associate geographical location with comradeship and belonging to others, most of whom will never be met, but whose presence gets actualised in mediated symbolic relations enacted with relation to phenomena such as language, religion, dress, cuisine, and worked up in ritual, ceremony, and the assertion of 'tradition' (Cohen, 1985; Johnson, 1995).

The present study explores the intersections between emotion, morality, crime and ASB by analysing audio recordings of the meetings of two community groups. Whilst both groups are constituted geographically with respect to a fairly small, clearly defined inner-city area, they are also predicated on the notion that their actions should be in the best interests of all local residents within that area, to this extent the community they embody is also a symbolic one. The data are naturalistic, based upon recordings of meetings that would have occurred anyway; there are various reasons why this kind of data is particularly suited to an investigation of the nexus of associations between morality, emotion, crime and ASB. Because the data were not produced with respect to the kinds of formal social science research agendas, categories and interests that frequently 'saturate' interview data (Potter \& Hepburn, 2005), the incidents of crime and ASB were those spontaneously produced by the participants: consequently, definitions of crime and ASB are those made by participants, rather than those of researchers. Similarly, the emotional responses and moral stances associated with these incidents of crime and ASB were similarly unconstrained as participants reacted entirely freely to each other in the course of meetings. Moreover, the data contain unregulated sequences of group interaction where constructions of crime and ASB coincide both with enactments of emotion and with moral stances; it is within such sequences or 'situated lines of action' that the import of emotions, as forms of social action, becomes most readily apparent (Ginsburg \& Harrington, 1996; Goodwin \& Goodwin, 2000).

\section{Method}


Data consist of audio recordings of meetings of two community groups, made between June 2006 and May 2009 in a deprived area of Nottingham UK, a city notable in recent years for its high crime rates - especially gun crime. City-level statistics may overstate Nottingham's problems: its strikingly high per capita crime rates are partly an artefact of the particular way local authority boundaries are drawn. Nottinghamshire [p.878] as a whole reported 109 offences per thousand people for 2008, compared to a national average of 86 (Walker, Flatley, Kershaw \& Moon, 2009 ); although recorded crime in the county fell by around $8 \%$ during the datagathering period (ibid.), offending rates in most of the inner city-areas of Nottingham that the groups represent were consistently higher than the county average. The area is ethnically diverse, with significant levels of income deprivation, unemployment, poor health, disability and pensioner poverty (Nottingham City Council, 2004; Nottingham Crime and Drugs Partnership, 2009).

Both groups are supported by a charity that forges links between business, local government and community to regenerate the area. The 'Tidy Our Community' (TOC) group manages limited resources in an effort to make the local environment cleaner and friendlier; the 'Watch Our Community' (WOC) group works with community representatives and institutions to monitor and improve community safety. Issues relevant to crime and ASB were recurrent topics of conversation in both: the WOC group take crime and ASB as their explicit focus, whilst the (controversial) 'broken windows' theory that neighbourhood disorder and disarray cause criminal activity (Wilson \& Kelling, 1982) explicitly links the work of the TOC group to crime and ASB (Nottingham Crime and Drugs Partnership, 2009).

There was considerable overlap between membership of the groups, with both consisting of largely the same core of local residents: it was not possible to systematically gather demographic information, but these people tended to be equally likely to be female or male, older (many were in their 40's, the oldest in his 70's), predominantly Caucasian, and resident in the area for some considerable time. Membership was quite stable, although the number of local residents present at each meeting varied between five and twelve. Meetings also included representatives of other institutions and community bodies: a church, a drop-in centre, other local 
charities, community wardens, Community Protection Officers and Police Community Support Officers. On occasion, representatives of other groups and institutions (the City Council, the University) were invited to attend. All meetings were facilitated by a paid worker.

Informed consent was separately given by each participant; if anyone withheld consent, the meeting was not recorded. Eighteen meetings were recorded (thirteen TOC, five WOC), generating twenty-four hours of data. Recordings were first transcribed for content by a professional transcription service; subsequently, selected sections were re-transcribed following the conventions described in Jefferson (1985). Data were then subjected to an affective-textual analysis using techniques drawn from conversation and discourse analysis. Wiggins \& Potter (2008) note that embodied responses are often bound up with spoken interaction and can be analysed using discursive techniques, and Goodwin \& Goodwin (2000) show how the rapidity of turn-taking and shifts in pitch, volume and speed are discursive traces of affective force and embodied emotionality, interpretable within the action sequences where they occur. Similarly, Stokoe \& Wallwork (2003) show how conversation and discourse analyses can be used to explore the workings of a moral order, through focusing on participants' constructions of 'good' or 'bad' others, and by exploring how the categories participants deploy "align and re-align the social and moral order and establish some version of events as social 'fact' .. or as constituting common knowledge about what defines appropriate and moral behaviours" (p.556). Thus, the meetings were a suitable site for the exploration of moral activity, and detailed examination of the rhythms, prosody and turn-by-turn organisation of their talk might render its emotional aspects tractable.[p.879]

\section{Analysis}

As might be expected in this task-oriented setting, levels of overt emotion are relatively low across the data corpus; only laughter and amusement are frequently overtly enacted, although utterances were frequently imbued with varying degrees of affective force or determination. An analysis detailing the variety and character of emotions enacted in relation to crime and ASB nevertheless identified five major emotion clusters in the data: nervousness and not feeling safe, humour and 
amusement, anger and indignation, irritation and frustration, and resignation

(Cromby, Brown, Gross, Locke, \& Pattterson, 2009). The analysis below is organised into three sections: first we examine how moral categories such as responsibility, consideration and respect are worked up and applied by participants; second, we show how participants develop moral hierarchies by constructing 'good' and 'bad' versions of people and groups; and third, we illustrate some of the ways in which moral judgements are enacted by invoking the particular needs of specific groups of people. In all three sections, we consider the extent and the manner in which affective force and emotional enactment contribute to the participant's activities of moral reasoning.

\section{Moral categories}

At various points in the data, participants explicitly invoke moral categories such as responsibility, consideration and respect. In the first two extracts, participants work up responsibility and a 'duty of care' with regard to two large companies: an ASDA supermarket where a new covered walkway may invite street drinkers to congregate, and a transport company ('LOT'):

\section{Extract 1: WOC1}

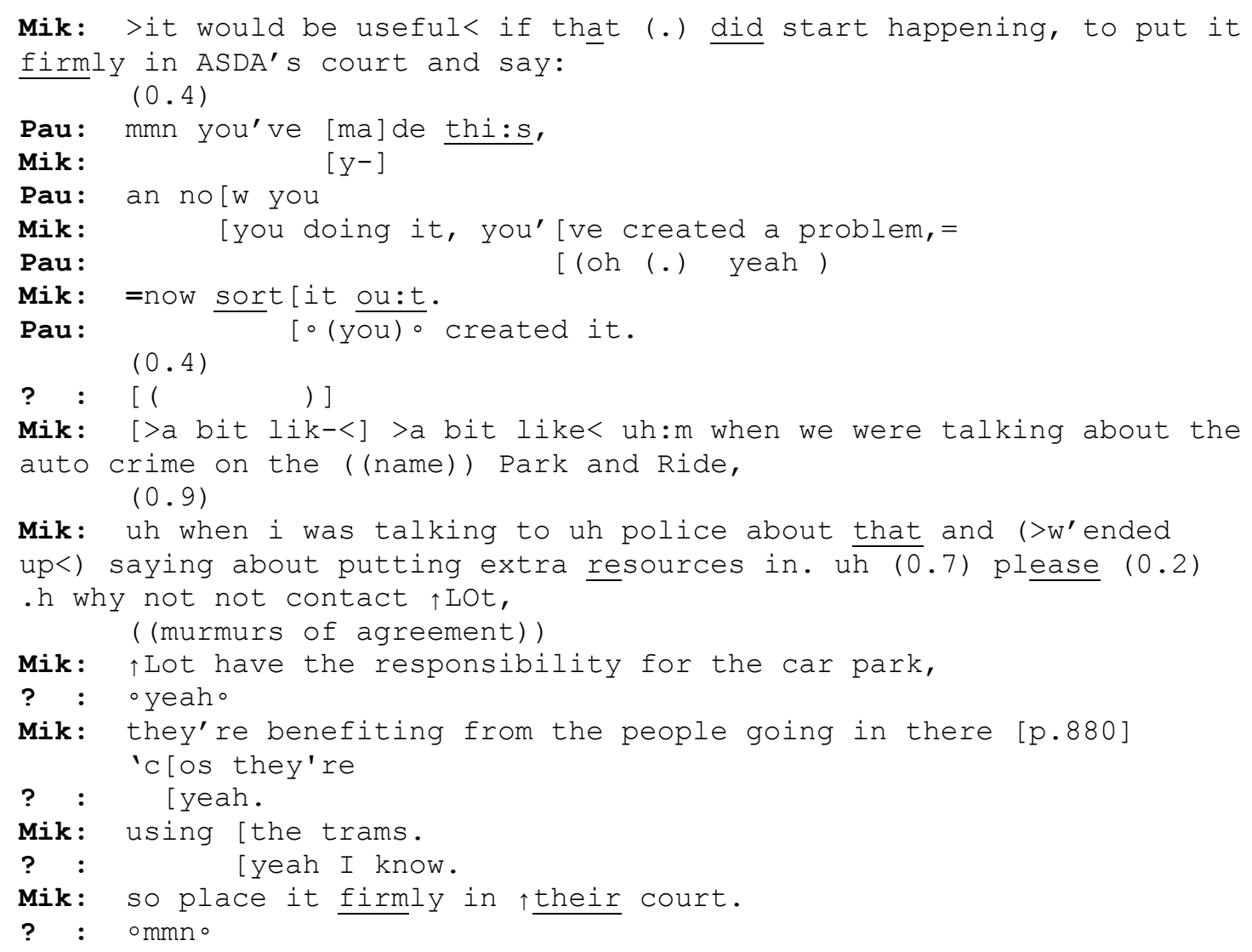




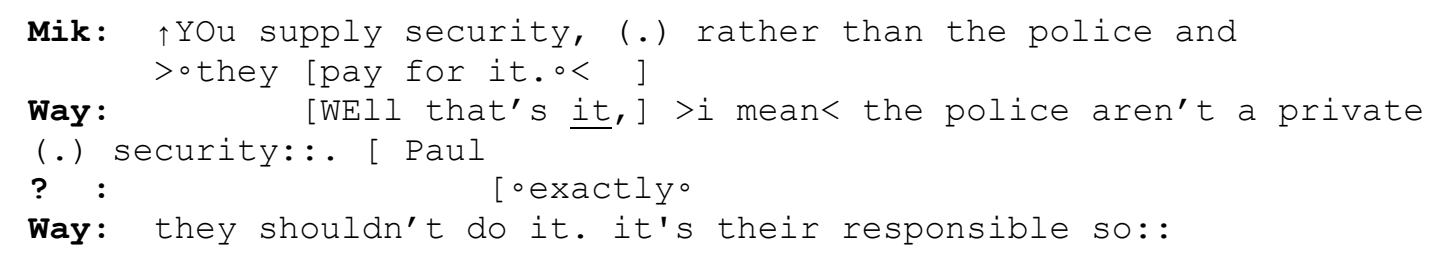

As the extract begins, Mike and Paul are jointly constructing the problem caused by ASDA, giving their concern immediacy and moral force by using active voicing (Wooffitt, 1992). In their talk it is as if they could somehow speak directly to the supermarket, as though it were a person with moral obligations like anyone else. At line 14, Mike then links this problem with ASDA to one previously discussed with regard to the transport company, LOT, noting similarities between them. As the talk progresses it is clear that the equivalence here is as much moral as practical, since in each case the company concerned is being held responsible for a problem caused by their ordinary activities. Throughout, affective force is enacted by repeated patterns of emphases (e.g.: 'you've made this'; 'now sort it out'), whilst the frequent turn-taking with occasional overlaps and completions suggests something of the intensity of the group's joint engagement, an interpretation further supported by the presence of background vocalisations concurring with the main speakers (line 19). Whilst responsibility is explicitly invoked only twice, by Mike (line 20) and Wayne (line 34), in the next extract it becomes explicitly clear that equivalent moral responsibility is being imputed to both ASDA and LOT: 'responsibility' is further ratcheted up to 'duty of care', a phrase invoking not just morality but legality; and at lines 5-7 Paul neatly summarises how this moral obligation falls equally on both companies, a judgement with which Mike concurs:

\section{Extract 2: WOC11}

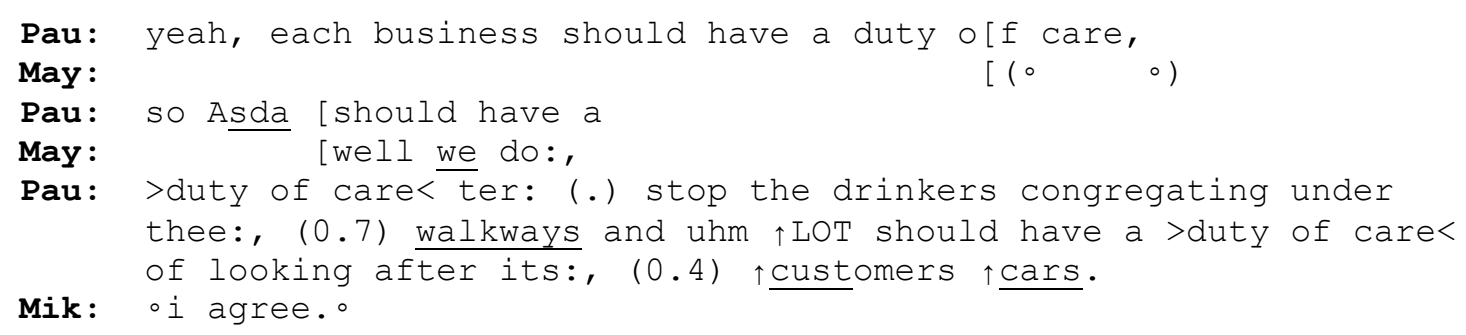

Moral categories of consideration and respect are also sometimes invoked; in extract 3 we see both of these deployed in relation to ASB by students coming home late at night and making unwarranted noise: 


\section{Extract 3: TOC6}

Ste: they come back from town about two three in the morning.=they make so much noise and the local residents think (0.5) you're only here for a year or some'at an $y^{-} y^{-}$you're makin our life a misery. [p.881]

Leo: $\mathrm{mm}:$, on th- >on the other hand, < tha- that- that is what students do at that a:ge.

Ste: ${ }^{\circ}$ yea $: h^{\circ}=$

Leo: =>i mean the-< (0.7) I'M sure I di:d a- a:n: $\mathrm{d}^{\circ} \mathrm{uh}^{\circ}(0.3)$ perhaps-= perhaps the uh- we uh all did at one point. uhm (0.6) so pperhaps there's a need< fo:r slightly greater: understanding there: on: both sides. $\overline{(0.4)}$

ste: thats right yeah.

Leo: $\mathrm{mm}:$ : . $(0.5)$

Mik: can i- $(0.2)$ can i a $\left[\mathrm{sk} \mathrm{w}^{-}\right.$

?: [ no $1-$

Jun:

Bar:

[don't know about that]

[ I: Do:n't agr: ] ee:

?:

Bar:

[ 1

(0.2)

Bar: bloody makin a racket in a- an that $t \downarrow$ ime of the $\downarrow$ morning=

?: $\quad \circ \mathrm{mm}^{\circ}$

Bar: its-its not $\mathrm{ON}^{-}$ (0.2)

Leo: $\mathrm{mm}:$ : I: : agree it's not on,

?: (well its not [jus,

Bar: [it ain: on. they want telling abou:t it

Leo: yea:h, [( (several other turns going on at once))

$(0.3)$

Leo: ye: : $[s=$

[((remnants of other conversation in background))

Leo:

[On: : the other hand, we: : ought to understand ththe-=

Ste: =>no offence against students by the way.<

Leo: [they don't-

[((general laughter [laughter continues in background))

Leo:

$(>\quad<)=$ at that age $(0.4)$ i:: quite [they don't int $\downarrow$ end to

often think that they- that they don't think about that you know,

$(0.5)$

Leo: an: $[d: i:::]$

Bar: [but(.)i]ts called having consideration for othe[rs

$r[$ es $[$ pect

Leo: $\quad[(i::-$

?: [( (several voices - mixed talk and laughter)) [p.882]

Bar: [i- i mean they're only in transit $\downarrow$ anyway: until they: [ve, finish:ed ] 


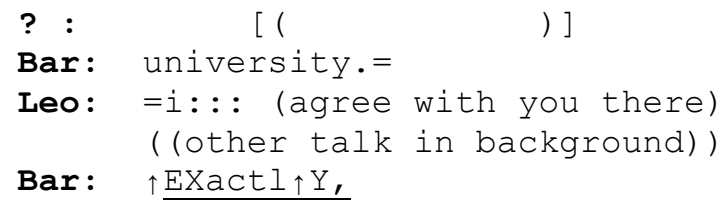

The extract begins with Steve's description of the problem, a description already tailored to invoke a moral stance. Simply returning from town at an unsociable hour is unremarkable, but its formulation both as a continuous, pervasive problem (seemingly always 'about two or three in the morning') and as involving a quantity ('so much') of noise helps manage it as a 'reasonable' complaint. Moreover, the complaint is not Steve's, but is expressed in terms of local residents' 'thoughts'. This 'footing' (Goffman, 1979) has the dual effect of generalising the issue as one affecting numerous others, whilst also effacing any apparent personal stake that Steve may have in raising it (Potter, 1996) In these ways, the student's behaviour gets constructed as anti-social, so causing 'our' lives to become 'a misery'.

An alternate judgement of the students' behaviour is then offered by Leo (line 5-6), accompanied by an attempt to reformulate the issue as one of mutual consideration and understanding (lines 8-11). This produces some disagreement amongst the group, and in response to further attempts to construct the problem as mutual, Barry first restates Leo's position ( a need for "understanding there on both sides"), but using a questioning intonation to produce it as something that is incredulous. Then, on lines 27-28), he reformulates Steve's original complaint into a much stronger version, using an if-then formulation which suggests that an alternative perspective (and attendant actions) might be emerging. Steve's reference to noise is ratcheted up to "bloody making a racket" (line 27) and the unsociability of it occurring in the early hours is reiterated ('that time of the morning'). Repeated emphases add affective force and help reinforce the 'then' aspect of the if-then formulation ('it's not on': line 30), leading to his suggested action, which again is affectively loaded using emphases (line 34: 'they want TElling abou:t it'). So: (IF they're) bloody making a racket (THEN) it's not on, they want telling about it", a formulation clearly hearable as anger or indignation.

Despite the affective force of Barry's turn, Leo continues to pursue a more tolerant stance by offering an explanation for the student's ASB based upon their immaturity 
(line 42). The overall emotional tone remains mostly good-humoured (line 44), but disagreement continues and Barry introduces notions of 'consideration' and 'respect'. The phrase 'its called having consideration for others' (line 51) indexes consideration as something 'out there', objectively available for all to recognise; his next turn uses the same formulation, but this time citing 'respect' as the objectively recognisable moral category. Together, these lines construct consideration and respect as readilyvisible elements of a generally accepted moral code, which the students' ASB is breaching. He completes his argument by addressing the temporal dimension of the problem (first visible in Steve's initial turn), noting that students are 'only in transit anyway': line 56). The emphatic loading of this turn, together with its position at the end of a sequence building a moral judgement, thus reinforces the judgement by suggesting that students should perhaps be more considerate and more respectful, precisely because they are not permanent residents.[p.883]

\section{Moral hierarchies}

In this section we show how the participants work up neighbourhood problems into moral issues by making contrasts between good and bad groups, kinds of individuals, and behaviours. In extract 4 they are discussing cycling on the pavement:

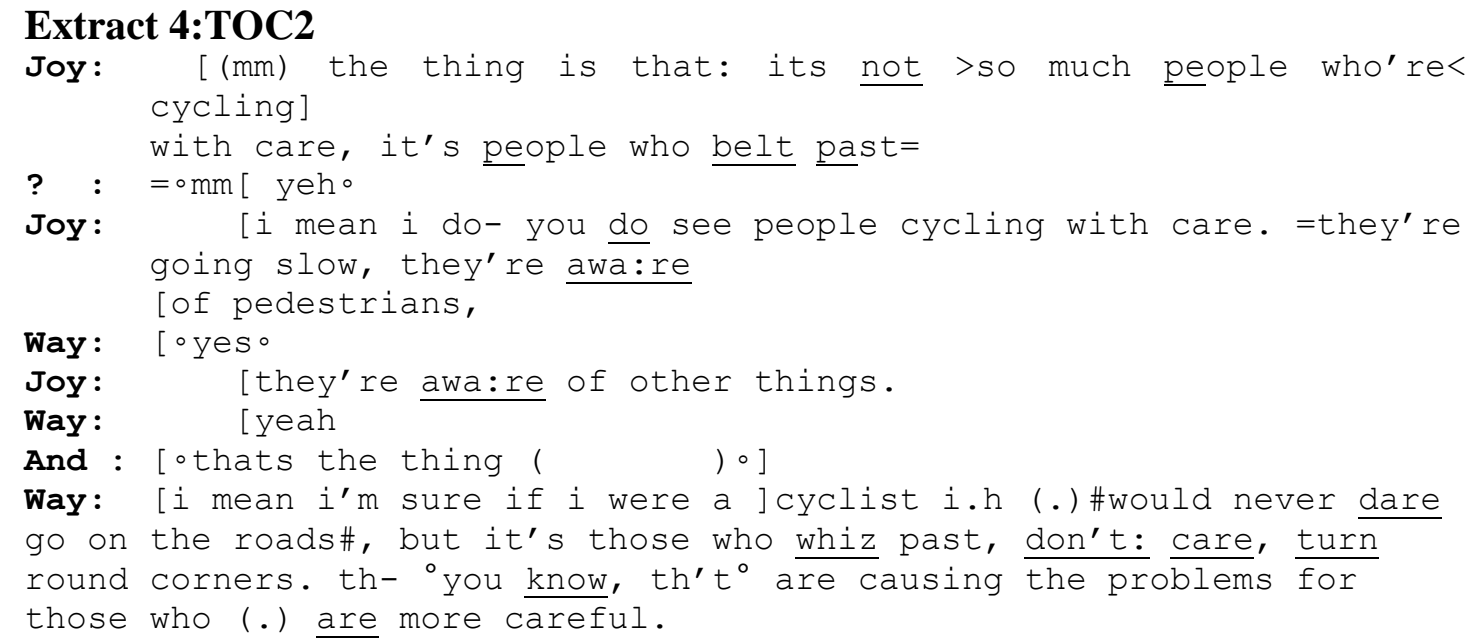

Here we see Joy constructing two differing 'types' of cyclist; those "cycling with care" and those who "don't care". These are not just opposites, they are also differently formulated: whereas 'cycling' can be done with or without care, saying that some cyclists 'don't care' is to attribute their actions to a personal disposition of showing disregard for others, so favouring a moral assessment rather than a simple 
description. The participants use two three-part lists to contrast the careful cyclist with the cyclists who don't care: careful cyclists go slow, are aware of pedestrians and aware of other things (lines 5-7); careless cyclists whiz past, don't care and turn round corners - presumably without knowing what is around them (lines 13-14). Atkinson (1984) showed that three-part lists are potent rhetorical devices that tend to elicit powerful, emotion-laden agreement; he also found that contrasts, too, recruit emotive responses. Hence it is notable that 'slow' cycling is not contrasted with a reciprocal level of speed (fast) but with metaphorical expressions (flying, whizzing, belting past) that further upgrade the 'bad' behaviour of the 'non-caring' cyclists. The contrasts are given further affective force both by (some) repeated emphases, and by a prosodic difference: compared to the talk about bad cyclists, the talk describing good cyclists is noticeably slower, with relatively elongated vowel sounds: here, the character of the talk itself hearably invokes the more measured and careful style of cycling that is favoured. Thus, a combination of emotive rhetorical devices and affective enactments are combined to work up a moral judgement about 'good' and 'bad' cyclists.

Similar strategies are also deployed elsewhere; one lengthy conversation discusses a local park where two contrasting groups of users are identified: 'fire-jugglers' and 'drunks':

\section{Extract 5: TOC5}

Ste: (certainly) there's a lot'a'lads guh:' in the n†ight time (0.1) [p.884] have a session of drink, they think it's a nice quiet place, nice scenery, ' $y^{\prime}$ knowo they just abłuse it.

Steve characterises the 'drunks' as people who 'abuse' the park, which is constructed as a 'nice quiet place'; this construction, together with the combination of intonation and emphasise on 'abuse', conveys something hearable as contempt or disgust for this group. Very shortly after this, Wayne first introduces and then describes the fire jugglers:

\section{Extract 6: TOC5}

Way: they're usually up on the bank.

$(0.5)$ yeahi $(0.2)$

Way: sometimes they go in the middle of the field=depends how busy it is. 


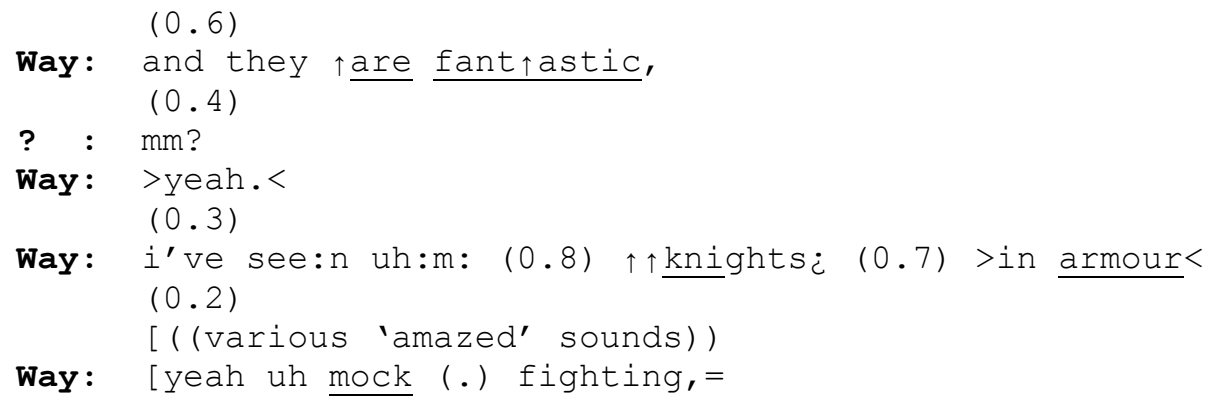

As Wayne's description develops over numerous turns it is laden with significant pauses, perhaps as he checks for 'permission' to continue from other group members. On line 20 the pattern of emphases and intonations on 'fantastic' hearably enacts the wonder it attempts to describe, and then sparks a further 'amazing' reminiscence of seeing 'knights in armour' on the park. The moral dimension of his affection or enthusiasm for this group then becomes explicit some lines later when they are explicitly contrasted with the 'drunks':

\section{Extract 7: TOC5}

Bar: (thats right)

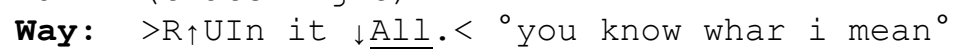

The emphases and intonations of Wayne's 'fantastic' on line 43 resemble the earlier occurrence of the word and gain further relevance because of the lengthy pause afterward, immediately following which the contrast with 'drunks' appears. Now the emotion is carried mainly in the volume and pitch shifts on 'ruin it all'; this construction, similar to Steve's construction of 'abuse', enacts a disapproving and perhaps disgusted emotional tone, contrasting sharply with the admiration and enthusiasm preceding it. Thus in this extract much of the moral dimension is carried by contrasting emotions of [p.885] wonder/amazement and disgust/contempt, but as the next extract shows this is not always the case:

\section{Extract 8: TOC6}

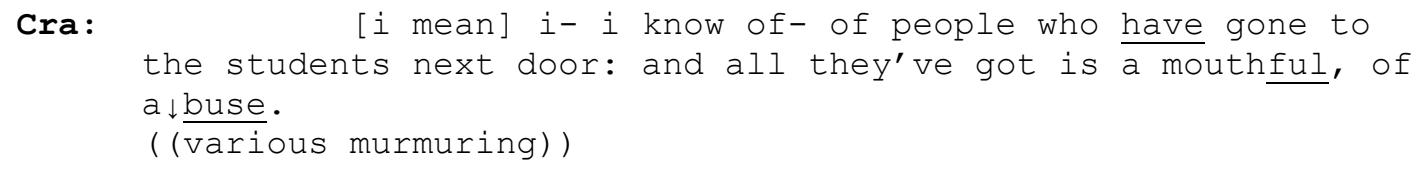




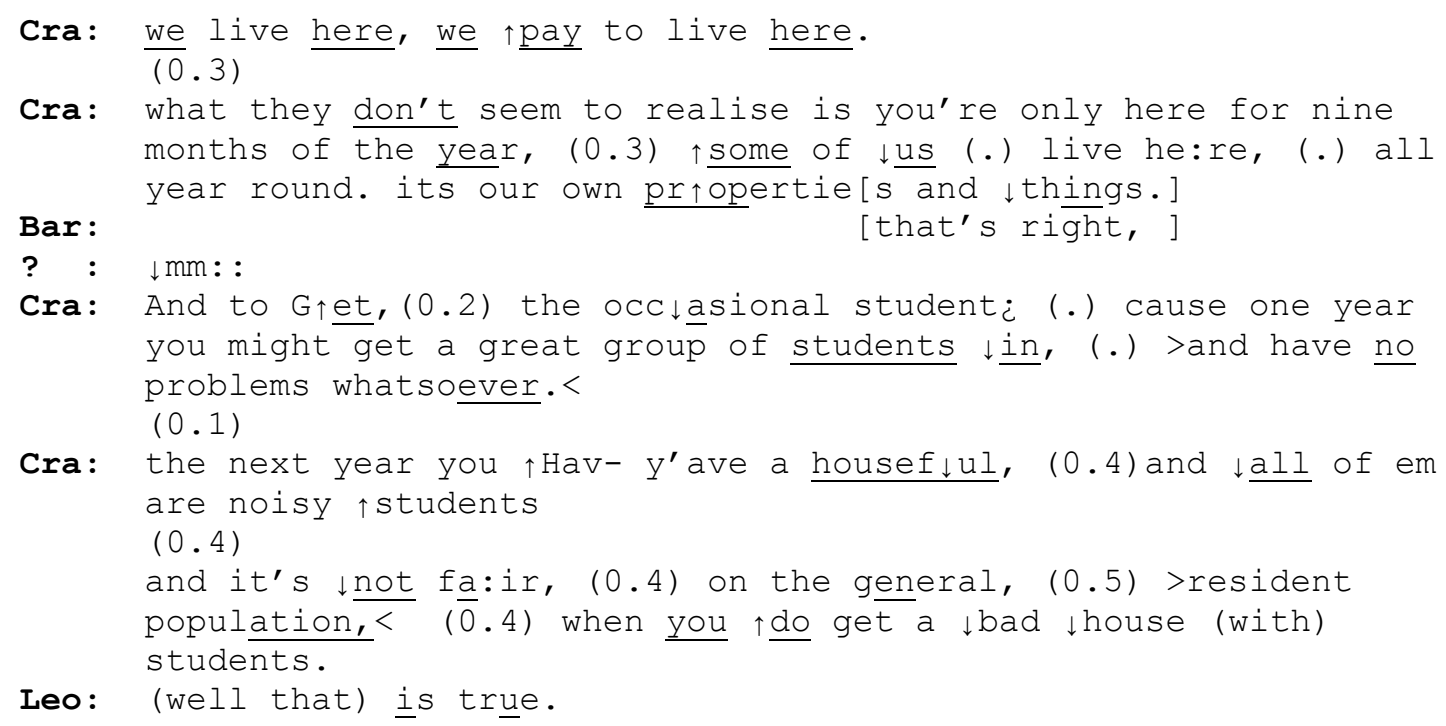

Craig refers to the transient nature of students and contrasts this to residents, including himself ("some of us" line 8), who are long-term residents or owners (line 9).

Similarly on lines 12-14 and 16-17 he contrasts a "great" group of students, who do not pose problems, with a 'houseful' who are 'noisy': here, the term 'houseful' itself invokes an image of chaos, disorder, uncountable numbers. This distinction subsequently helps produce another, between the 'general resident population' and a generic 'bad' house of students (lines 19-21). These nested contrasts constitute 'residents' as simply 'there' and students as either 'good' or 'bad', and their contribution to a moral case becomes explicit as the notion of fairness is introduced. Notably, although Craig stresses some words and phonemes to emphasise contrasting aspects of students behaviour, his delivery is hearably 'matter-of-fact' and emotionally neutral. His turns follow the heated discussion analysed in extract 3 , where frustration and anger were enacted in relation to student behaviour, and in this context his carefully neutral delivery provides 'fairness' or 'balance'. However, as Brennan (2004) observes, emotional neutrality is not the same thing as indifference; the measured emphases and intonations in Craig's talk enact its sensitivity to the affective context into which it fell, rendering it as carefully neutral within, yet entirely entirely sensitive to, the heated context preceding his turn.

In extract 9 we see two contrasts being simultaneously worked up as part of an orientation to some kind of hierarchical arrangement of 'problem' situations and behaviours: 


\section{Extract 9: TOC6}

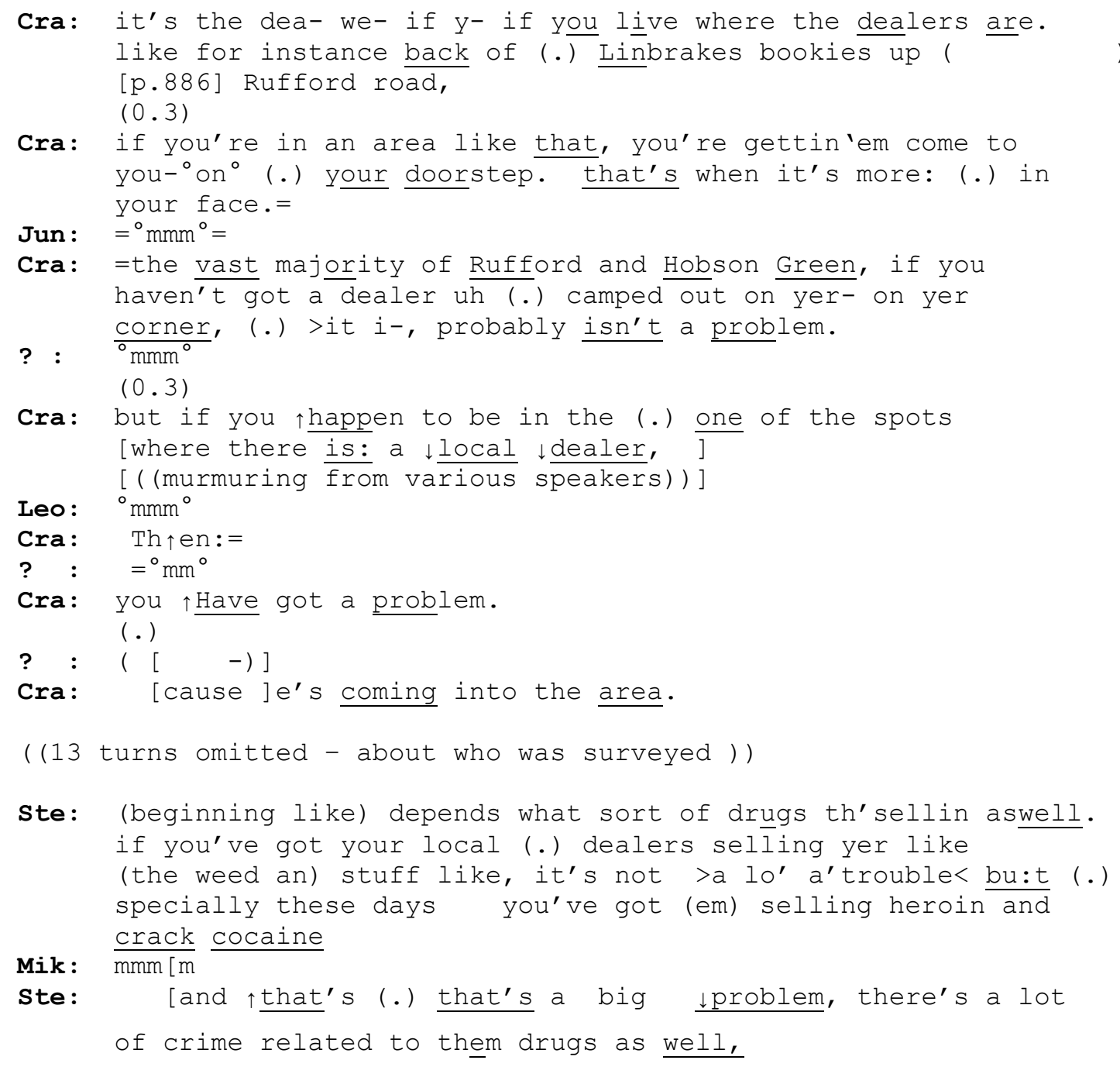

Participants are discussing the extent to which drug-dealing is a problem, and single out a particular area. At line 5 Craig describes the immediacy of the problem in terms of drug-dealers coming on "your doorstep" and being "in your face"; in line 10 he contrasts this scenario with one where you haven't got a dealer "camped out on your corner". These are all extreme case formulations (Pomerantz, 1986) that emphasise the proximity of the problem to some people and highlight its intrusiveness, being on your doorstep and in your face and on your '(yer') corner. Notably, however, drugdealing per se is not constructed as problematic; the extent to which it is problematic is dependent upon a hierarchy of proximity and place. Then, at line 27 Steve alludes to a further hierarchy which problematises some drugs in comparison to others: 'weed an stuff' are indexed as less troublesome than heroin and crack cocaine. On lines 3031 he further develops this construction, suggesting that the sale of the latter two has 
an element of crime attached to them. Although all recreational drug-dealing is illegal and therefore, by definition, criminal, a hierarchy is constructed here that separates the dealing of 'weed an stuff' from the dealing of other drugs. In this extract, then, hierachical levels of 'problem' get constructed with relation to both place and 'crime'; throughout, the many emphases and shifting intonations endow these hierarchies with some affective force. Notably, [p.887] despite the affects enacted, no-one questions these hierarchical constructions, suggesting that they accord with local shared knowledge and with the group's normative understandings of what might be construed 'troublesome' and 'less troublesome' drugs.

\section{Invoking Others}

Finally, moral judgements were also worked up by invoking both specific groups and specific places associated with their activities. Frequently, these were groups who might be widely considered 'vulnerable', such as children and people with disabilities: consequently, some of the moral work was conducted pre-emptively, since their mere invocation of these categories of people already carries a normative range of expectations and responsibilities that would not necessarily attach to others. In extract 10, for example, both children and people with disabilities get recruited as part of a moral case against local builders who leave skips and bags of rubble in such a way that they block pavements:

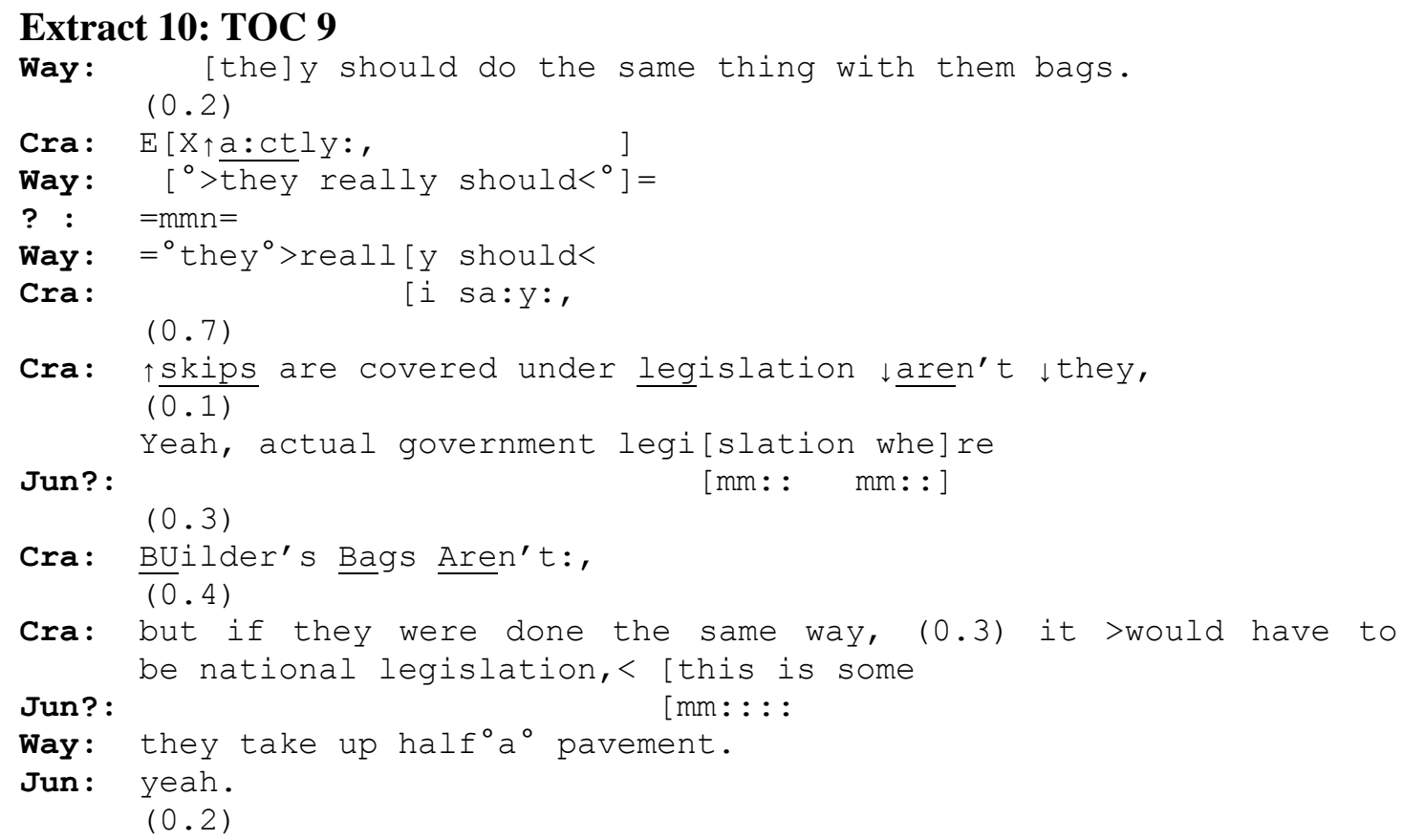


Way: people wi' >you know< wheelchairs, people in >pushchairs<, (0.1) you've gorra $\downarrow$ double $\downarrow$ buggy you've got cross the $\downarrow$ road.

Jun: yea:h

$(0.2)$

Way: you [rea:lly 'ave,

Although legality is discussed, the moral case is worked up primarily in terms of inconvenience to pavement users, specifically (lines 22-23) wheelchair users and those with pushchairs: people with a disability, and children. Whilst both these groups could be considered to have some additional vulnerability, the moral implication is nevertheless strengthened by a claimed imperative (that they have "got" to cross the road when builders' bags block pavements), and further reinforced by a downwardly intoned, [p.888] heavily emphasised delivery, which enacts a kind of mild 'outrage' with a situation where, in particular, people with double buggies are forced to cross the road. The moral case, then, is that leaving builders bags on the pavement removes choice, produces inconvenience and perhaps even (by needlessly crossing the road) exposes vulnerable people to danger. Extract 11 also sees the participants invoking children, as part of a moral case against an ongoing problem of anti-social noise:

\section{Extract 11: WOC11}

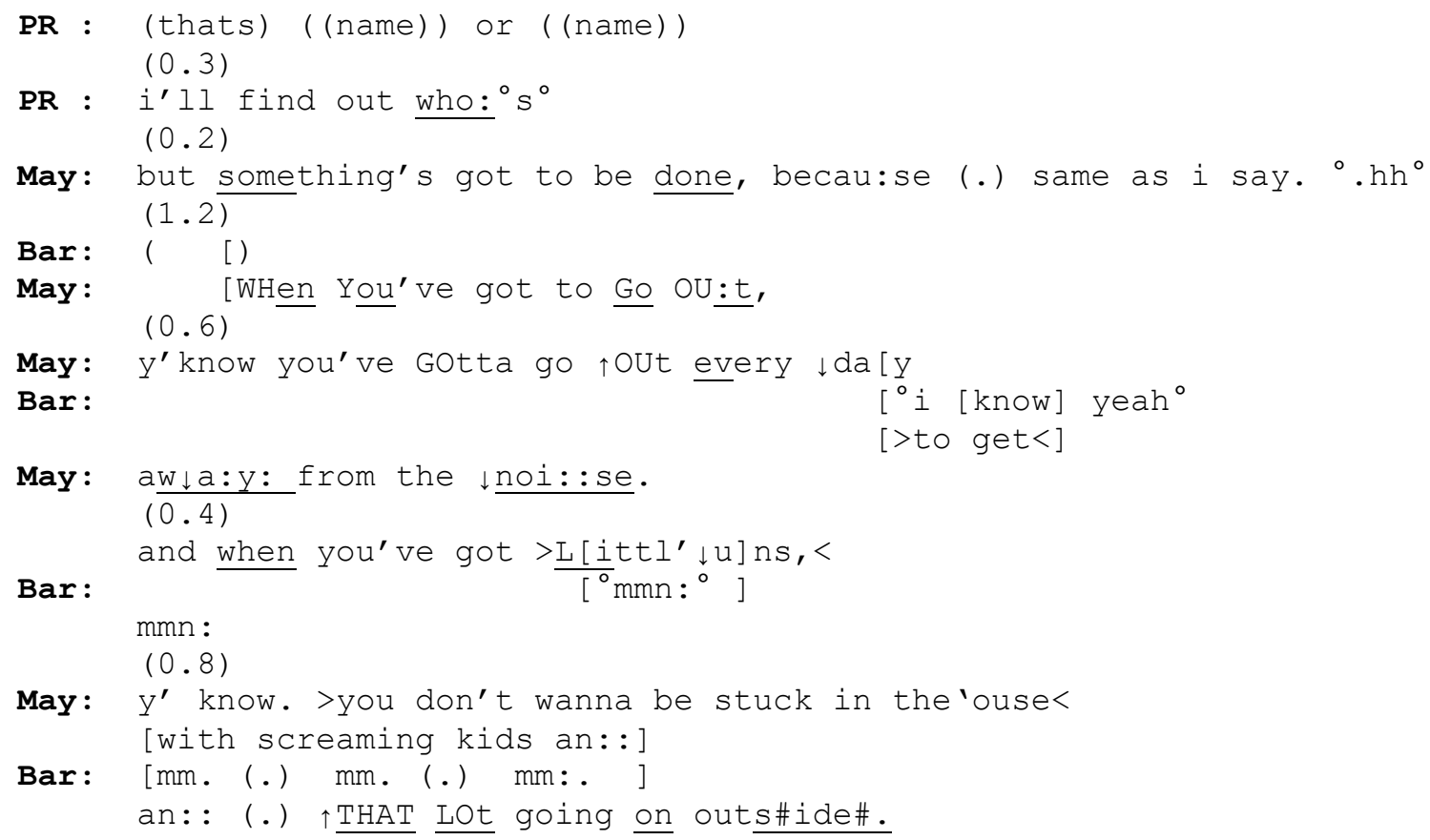

The group have previously discussed this problem at length, and at line 5 May begins building an argument for why it has to be resolved. In lines 8 and 10 she talks of when people have "got" to go out, "every" day, to escape the noise. Her talk is animated 
throughout, with multiple emphases and rapid shifts in tone and volume. At line 15 she begins spelling out the impact on children. The endearing construction " $L[i t t l ' \downarrow u] n s "$ serves to heighten the difference between the unbearable loud noise on the one hand and the potential vulnerability of young children on the other, although she then suggests that the children might be "screaming kids" and that the problem noise would compound the pressure on whoever is with them. May's delivery is affectively charged, notably the loudness with which she delivers lines 8,10 and 22 and the rising and falling intonation throughout lines 10, 13 and 22, features that hearably enact her 'frustration'. Together, both the content of her talk and its emotive delivery build the moral case that this problem should not have to be tolerated.

Finally, children are again invoked in extract 12, this time with respect to the issue of dog-fouling near to a school:

\section{Extract 12: TOC9}

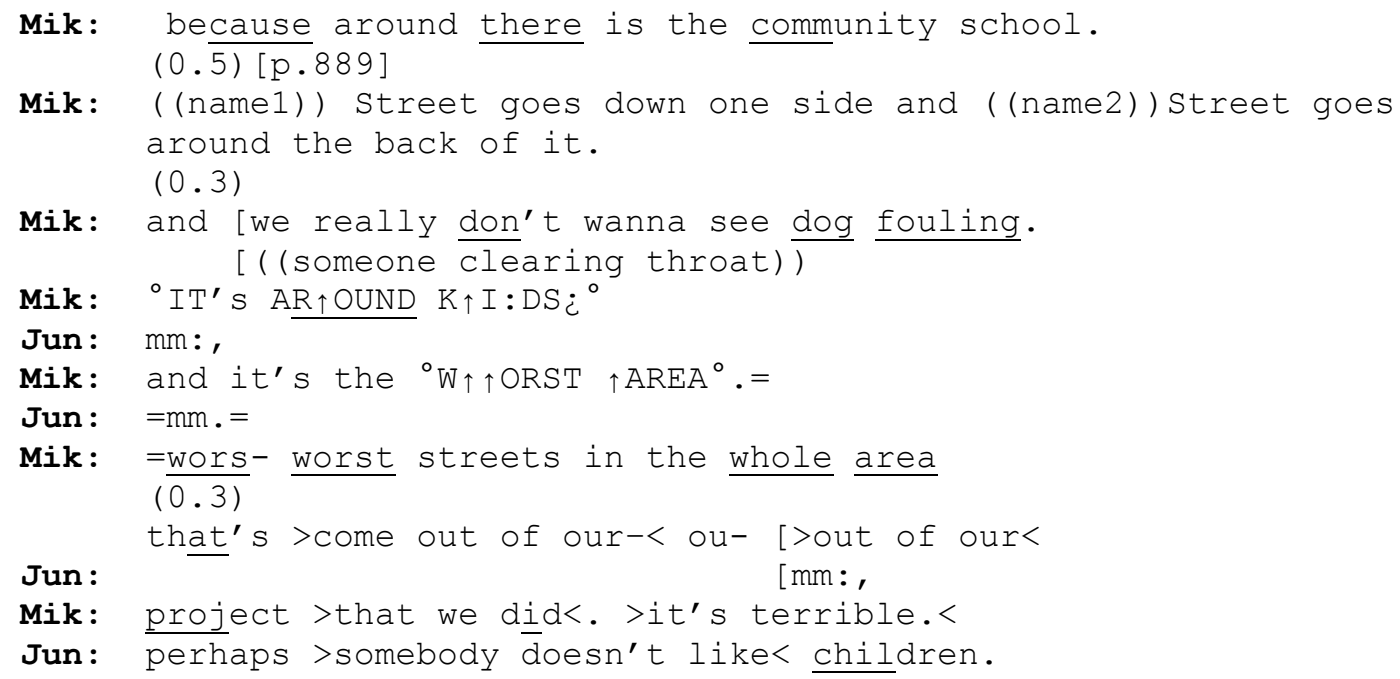

In this extract, the invocation of children ('kids') on line 8 is notable for its highly emotive delivery. The raised volume, emphasis on 'around' and pitch shifts within the turn render it hearable as enacting incredulity and indignation that anyone might allow their dogs to foul the pavement near the school. This is reinforced on line 10 with a similarly charged extreme case ('the worst area'), and again on line 12 with a more measured delivery that nevertheless repeats the previous extreme case. Across these turns, Mike delivers a moral judgement both with the invocation of children and with the emotionally-charged way in which the problem is described. 


\section{Discussion}

Our analysis has revealed aspects of the situated morality of residents of an inner-city area with high rates of crime and ASB, and shown how their moral reasoning and judging enrols various kinds of emotional enactments and affective stances. As psychologists, we can speak only tentatively about the implications of this work for colleagues in criminology, and we remain aware that our study and data are necessarily limited in both their scope and generality. There are nevertheless some features and implications of the analysis that we would like to draw out more explicitly in this closing section of the paper.

First, we wish to emphasise that, throughout our data, participant's constructions of crime and ASB were not separate either from their moral reasoning or their emotional enactments: all were thoroughly bound together. As participants jointly defined problems of crime and ASB, they simultaneously worked up moral arguments that made the incidents they discussed count as crime and ASB, and these arguments typically recruited emotional enactments and marshalled degrees of affective force. Rather than first making a definition and then allowing their reasoning to proceed from it, participants' definitions and reasoning were nested together; simultaneously, both were bound up with, carried by, and in part enacted through, interwoven and concurrent affective exchanges. Illustrating the contention that an emotional point of view might enrich criminology (De Haan \& Loader, 2002), our data demonstrate that the lay norms of everyday social action, by which crime and ASB are in practice identified, already include marked affective components. Their shared assertion and mutual accomplishment was [p.890] consistently conducted, in part, through a variety of reciprocal, relationally meaningful, affective flows and stances; and to the extent that this is a general phenomenon, it suggests that criminology could legitimately extend its engagement with emotion and consider the affective dimensions of other topics. This strategy might, for example, illuminate definitional problems such as those associated with the plural, differential and contextually nuanced character of ASB (Millie, 2008). It might also illuminate aspects of the fear of crime paradigm, where it is increasingly clear that fear of crime has historically been overstated, that crime calls out other emotions as well as fear (Phillips \& Smith, 2003), and that these 
emotional responses are nuanced according to the particulars of place and experience (Pain, 2000; Walklate \& Mythen, 2008). Our findings further emphasise this particularity and variability, and reinforce the possible value of calls to relate work in this paradigm to studies of 'everyday' emotion (e.g. Jackson, 2004).

Second, it is notable how thoroughly the morality of our participants is localised, and how it both accords with, and diverges from, the moralities encoded in law and associated with government policies. Millie (2009) observes that definitions of ASB are temporal, situational and aesthetic, and our data clearly show such variation. Commentators on government policy regarding respect and ASB have noted that respect is disproportionally expected from the already marginalised: notably, our participants demand 'respect' from both large and small businesses (ASDA, 'LOT', local builders) as well as from the young people (noisy students, people who cycle carelessly) whom this policy most typically targets. Similarly, our participants' morality sometimes mirrors, and sometimes bypasses, legal codes and statutes. Although dealing in all three drugs is illegal, our participants distinguish between dealers of cannabis, who are constructed as relatively harmless, and dealers of heroin and cocaine. All cycling on the pavement is illegal, but nevertheless gets morally differentiated quite sharply according to the level of care with which it is conducted; conversely, the dumping of builder's rubble on the pavement is primarily discussed in moral terms despite its illegality being established. Karstedt \& Farrall's (2006) analysis of everyday crime noted that many people are selective about which laws to comply with, and linked this selectivity to a form of anomie associated with markets and 'moral economies'; our findings may enrich this analysis by showing how these moral configurations are thoroughly localised, and demonstrating that the corrosion of the market is not all-pervasive. Rather than an absence of morality, our participants' selective regard for the law instantiated a local, shared morality which sometimes took precedence. It might be tempting (especially considering its affective components) to dismiss this local moral reasoning as flawed and 'irrational; but we suggest that it is more fruitful to see it as sophisticated and differentiated according to the concrete particulars of the participants' social and material situation, and perhaps illustrative of the ways in which everyday crime, ASB and incivility are in actual practice frequently demarcated. Some criminologists (e.g. De Haan \& Loader, 2002, Ferrell 2003, Katz 1998) have argued for an understanding of the emotional, sensuous 
dimensions of criminal activity; our analysis suggests that a similarly affective understanding of its recognition and identification by others would also be valuable.

Yar (2009) observes that criminology, like many other disciplines, has historically treated emotion by polarising it against rationality. Whereas emotions were integral to the classic sociologies of Marx, Weber and Durkheim, the functionalism and scientism that dominated sociology in the last century have yielded a criminology largely predicated [p.891] upon narrow, calculative and utilitarian models of social action. In contrast, Yar argues for a criminology that does not separate reason from affect, a criminology that treats emotions as both embodied appraisals and meaningful social action, and which recognises how choices are informed by both 'emotional reasons' and 'reasonable emotions'. In our study moral reasoning was already partially affective, flexibly and consistently bound up with a range of emotional stances and displays; it both provides support for Yar's contention, and offers one possible methodology by which it might be furthered.

\section{Acknowledgements}

This work was funded by the ESRC under grant RES-000-22-2434 "Emotion and

Crime: a mixed-methods approach".

Thanks to Andrew Millie for his generous advice, and to the two anonymous reviewers for their helpful comments.

\section{References}

Allen, J., \& Hamnett, C. (1995). Introduction. In J. Allen \& C. Hamnett (Eds.), A Shrinking World? Global Unevenness and Inequality (pp. 1-10). Oxford: Oxford University Press.

Anderson, B. (1991). Imagined Communities. London: Verso.

Atari, S. (2008). The right to die: 'do not resuscitate': the Terri Schiavo case. How does hospice fit in? Journal of Medical Ethics, 34(11), 793-797.

Athanasiou, A., Hantzaroula, P., \& Yannakopoulos, Y. (2008). Towards a New Epistemology: the "affective turn". Historein, 8, 5-16.

Atkinson, M. (1984). Our Master's Voices: Language and Body Language of Politics. London: Routledge. 
Barrett, K., Zahn-Waxler, C., \& Cole, P. (1993). Avoiders versus Amenders: implications for the investigation of guilt and shame during toddlerhood. Cognition and Emotion, 7, 481-505.

Ben-Ze-ev, A. (1997). Emotions and Morality. Journal of Value Inquiry, 31, 195-212.

Benson, C. (2001). The Cultural Psychology of Self: place, morality and art in human worlds. London: Routledge.

BIBIC. (2005). Aint Misbehavin': young people with learning and communication difficulties and anti-social behaviour. Bridgwater: British Institute for Brain Injured Children.

Blackman, L., \& Cromby, J. (2007). Affect and Feeling. International Journal of Critical Psychology, 21, 5-22.

Brennan, T. (2004). The Transmission of Affect. Ithaca, New York: Cornell University Press.

Chakraborti, N., \& Garland, J. (2003). Under-researched and overlooked: an exploration of the attitudes of rural minority ethnic communities towards crime, community safety and the criminal justice system. Journal of Ethnic and Migration Studies, 29(3), 563-572.

Clough, P., \& Halley, J. (Eds.). (2007). The Affective Turn: theorising the social. Durham NC: Duke University Press.

Cohen, A. (1985). The Symbolic Construction of Community. London: Heinnemann.

Crawford, A. (2009). Governing through anti-social behaviour. British Journal of Criminology, 49, 810-831.

Cromby, J., Brown, S. D., Gross, H., Locke, A., \& Pattterson, A. (2009). Emotion, Crime and Anti-Social Behaviour: a social psychological analysis. British Journal of Social Psychology, under consideration.

De Haan, W., \& Loader, I. (2002). On the emotions of crime, punishment and social control. Theoretical Criminology, 6(3), 243-253.

Edwards, D. (1999). Emotion discourse. Culture \& Psychology, 5, 271-291.

Eisenberg, N. (2000). Emotion, Regulation and Moral Development. Annual Review of Psychology, 51, 665-697.

Ferrell, J. (2003). Tearing Down the Streets: adventures in urban anarchy. London: Palgrave Macmillan.

Fyson, R., \& Yates, J. (in press). ASBO's and young people with learning disabilities. Critical Social Policy.

Gadd, D., \& Jefferson, T. (2007). Psychosocial Criminology. London: Sage Publications.

Gallese, V., \& Goldman, A. (1998). Mirror neurons and the simulation theory of mind-reading. Trends in Cognitive Sciences, 2(12), 493-501.

Ginsburg, G. P., \& Harrington, M. E. (1996). Bodily states and context in situated lines of action. In R. Harre \& W. G. Parrott (Eds.), The Emotions: social, cultural and biological dimensions (pp. 229-258). London: Sage Publications.

Goffman, E. (1979). Footing. Semiotica, 25, 1-29.

Goodwin, M., \& Goodwin, C. (2000). Emotion Within Situated Activity. In N. Budwig, I. Uzgris \& J. Wertsch (Eds.), Communication: an arena of development. Stamford: Ablex.

Gray, E., Jackson, J., \& Farrall, S. (2008). Reassessing the Fear of Crime. European Journal of Criminology, 5(3), 363-380.

Greenberg, A., \& Bailey, J. (1993). Do Biological Explanations of Homosexuality have Moral, Legal or Policy Implications? Journal of Sex Research, 30(3), 245-251. 
Haidt, J. (2003). The Moral Emotions. In R. J. Davidson, K. Scherer \& H. Goldsmith (Eds.), Handbook of Affective Sciences (pp. 852-870). Oxford: Oxford University Press.

Hale, C. (1996). Fear of Crime: a review of the literature. International Review of Victimology, 4, 79-150.

Harris, K. (Ed.). (2006). Respect in the Neighbourhood: why neighbourliness matters. Lyme Regis: Russell House Publishing.

Hollway, W., \& Jefferson, T. (1997). The Risk Society in an Age of Anxiety: situating fear of crime. British Journal of Sociology, 48, 255-266.

Home Office. (2006a). Home Office Crime Statistics. Retrieved 6th November 2006, from http://www.crimestatistics.org.uk/output/Page1.asp

Home Office. (2006b). 'Respect' Action Plan. London: The Home Office.

Home Office. (2009). Respect members homepage (Publication. Retrieved 05/08/2009: http://www.respect.gov.uk/members/article.aspx?id=10090

Imordino-Yang, M., \& Damasio, A. R. (2007). We feel therefore we learn: the relevance of affective and social neuroscience to education. Mind, Brain and Education, 1(1), 3-10.

Jackson, J. (2004). Experience and expression: social and cultural significance in the fear of crime. British Journal of Criminology, 44(6), 946-966.

Jackson, J. (2006). Introducing Fear of Crime to Risk Research. Risk Analysis, 26(1), 253-264.

Jefferson, G. (1985). An Exercise in the Transcription and Analysis of Laughter. In T. A. van Dijk (Ed.), Handbook of Discourse Analysis Volume 3. London: Academic Press.

Johnson, N. (1995). Cast in Stone: monuments, geography and nationalism. Environment and Planning D: Society and Space, 13, 51-65.

Karstedt, S. (2002). Emotions and criminal justice. Theoretical Criminology, 6(3), 299-317.

Karstedt, S., \& Farrall, S. (2006). The Moral Economy of Everyday Crime: Markets, Consumers and Citizens British Journal of Criminology, 46, 1011-1036.

Katz, J. (1998). The Seductions of Crime: moral and sensual attractions of doing evil. Oxford: Basil Blackwell.

Katz, J. (1999). How Emotions Work. Chicago: Univ. of Chicago Press.

Locke, A. \& Edwards. D. (2003). Bill and Monica: Bill and Monica: Memory, emotion and normativity in Clinton's Grand Jury testimony. British Journal of Social Psychology.42, 239-256.

MacIntyre, A. (1985). After Virtue: a study in moral theory. London: Duckworth.

Miller, B. (1993). Collective Action and Rational Choice: place, community and the links to individual self-interest. Economic Geography, 68, 22-42.

Millie, A. (2008). Anti-Social Behaviour, Behavioural Expectations and an Urban Aesthetic. British Journal of Criminology, 48, 379-394.

Millie, A. (2009). Anti-Social Behaviour. Maidenhead: McGraw Hill/Open University Press.

Nayak, A. (2003). Through Children's Eyes: childhood, place and the fear of crime. Geoforum, 34, 303-315.

Nixon, J., Hodge, N., Parr, S., Willis, B., \& Hunter, C. (2008). Anti-social behaviour and disability in the UK. People, Place \& Policy Online, 2(1), 37-47.

Nottingham City Council. (2004). The English Indices of Deprivation, 2004. Retrieved 6th November 2006, from http://www.nottinghamcity.gov.uk/id_2004_report_only.pdf 
Nottingham Crime and Drugs Partnership. (2007). Respect for Nottingham. Retrieved 28/4/2010, from http://www.nottinghamcdp.com/index.asp?pageid=Respect_for_Nottingham.x $\mathrm{ml}$

Nottingham Crime and Drugs Partnership. (2009). Strategic Assessment 2008-9 (executive summary). Retrieved 20/4/2010, from http://www.nomadplus.org.uk/secure/Intelligence/policing\%20and\%20public $\% 20$ safety/key\%20strategies\%20and\%20plans/strategic\%20assessment $\% 20$ ex ecutive $\% 20$ summary $\% 20$ and $\% 20$ key\%20findings\%202008\%2009\%20v7\%5 D.doc.

Nottinghamshire_Police. (2010). Local Crime Mapping. Retrieved 23/4/2010, from http://maps.police.uk/view/nottinghamshire/

Pain, R. (1997). Social Geographies of Women's Fear of Crime. Transactions, Institute of British Geographers, 22, 231-244.

Pain, R. (2000). Place, social relations and the fear of crime: a review. Progress in Human Geography, 24(3), 365-387.

Phillips, T., \& Smith, P. (2003). Everyday Incivility: towards a benchmark. The Sociological Review, 85-108.

Pomerantz, A. (1986). Extreme case formulations: A way of legitimizing claims Human Studies, 9(2-3), 219-229.

Potter, J. (1996). Representing Reality:discourse, rhetoric and social construction. London: Sage Publications.

Potter, J., \& Hepburn, A. (2005). Qualitative Interviews in psychology: problems and possibilities. Qualitative Research in Psychology, 2, 1-27.

Sayer, A. (2005). Class, moral worth and recognition. Sociology, 39(5), 947-963.

Sayer, A., \& Storpor, M. (1997). Ethics Unbound: for a normative turn in social theory. Environment and Planning D: Society and Space, 15, 1-17.

Scheff, T., \& Retzinger, S. (1991). Emotions and Violence. Lexington, MA: Lexington Books.

Scraton, P. (2004). Streets of Terror: marginalisation, criminalisation and authoritarian renewal. Social Justice, 31(1-2), 130-157.

Sen, J. (2007). The power of civility. Development Dialogue, 49, 51-67.

Sennett, R. (2003). Respect: the formation of character in an age of inequality. London: Penguin.

Shotter, J. (1993a). Conversational Realities: constructing life through language. London: Sage Publications.

Shotter, J. (1993b). Cultural Politics of Everyday Life. Buckingham: Open University Press.

Silk, J. (1999). Guest Editorial: the dynamics of community, place and identity. Environment and Planning A, 1999(31), 5-17.

Smith, D. (1999). Geography, Community and Morality. Environment and Planning A, 31, 19-35.

Somerville, P. (2009). 'The Feeling's mutual': respect as the basis for co-operative interaction. In A. Millie (Ed.), Securing Respect: behavioural expectations and anti-social behaviour in the UK. Bristol: Policy Press.

Stokoe, E., \& Edwards, D. (2007). Mundane Morality and Gender in Familial Neighbour Disputes: . In J. Cromdal \& M. Tholander (Eds.), Children, Morality and Interaction. London: Equinox. 
Stokoe, E., \& Wallwork, J. (2003). Space Invaders: the moral-spatial order in neighbour dispute discourse. British Journal of Social Psychology, 42, 551569.

Stretton, D. (2006). Critical notice--defending life: a moral and legal case against abortion choice by Francis J Beckwith. British Journal of Criminology, 46(6), 1011-1036.

Taylor, I., Evans, K., \& Fraser, P. (1996). A Tale of Two Cities. London: Routledge. Tileaga, C. (2007). Ideologies of moral exclusion: a critical discursive reframing of depersonalization, delegitimization and dehumanization. British Journal of Social Psychology, 46(4), 717-737.

Tulloch, M. I. (2000). The Meaning of Age Differences in Fear of Crime: combining quantitative and qualitative approaches. British Journal of Criminology, 40, 451-467.

Tulloch, M. I. (2004). Parental Fear of Crime: a discursive analysis. Journal of Sociology, 40(4), 362-377.

van Stokkom, B. (2002). Moral emotions in restorative justice conferences: managing shame, designing empathy. Theoretical Criminology, 6(3), 339-360.

Walker, A., Flatley, J. Kershaw, C. \& Moon, D. (2009) "Crime in England and Wales 2008/9. Volume 1: findings from the British Crime Survey and police recorded crime" London: Home Office. Retrieved 12/6/2010 from

http://rds.homeoffice.gov.uk/rds/pdfs09/hosb1109vol1.pdf

Walklate, S., \& Mythen, G. (2008). How Scared Are We? British Journal of Criminology, 48, 209-225.

Wiggins, S., \& Potter, J. (2008). Discursive Psychology. In C. Willig \& W. StaintonRogers (Eds.), Qualitative Research in Psychology (pp. 73-90). London: Sage.

Wilson, J., \& Kelling, G. (1982). Broken Windows: the police and neighbourhood safety. Atlantic Monthly(March), 29-38.

Wooffitt, R. (1992). Telling Tales of the Unexpected. Harlow: Prentice Hall.

Yar, M. (2009). Neither Scylla nor Charybdis: transcending the criminological duality between rationality and the emotions [Electronic Version]. Internet Journal of Criminology. Retrieved 30/4/2010 from http://www.internetjournalofcriminology.com/Majid - Neither Scylla nor Charybdis.pdf 